Pamiętnik Literacki 2020, 4, s. 45-56

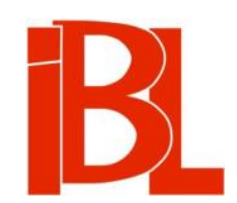

\title{
O szaleństwie edytorów w perspektywie ratio i praxis
}

\author{
Mirosław Strzyżewski
}




\section{O SZALEŃSTWIE EDYTORÓW W PERSPEKTYWIE RATIO I PRAXIS}

Czy szaleństwo w niektórych przypadkach można traktować à rebours jako doświadczenie pozytywne? Irracjonalność zawarta implicite w pojęciu szaleństwa niewątpliwie daje się usprawiedliwić w relacjach literackich. Bez „ludzi szalonych” lub „bezrozumnych”, szalonych historycznych satrapów czy kapłanów piękna albo wiary tudzież bohaterów poddanych ludycznej władzy obłędu literatura po prostu nie mogłaby istnieć, o czym przekonują choćby Michael Foucault i Walter Muschg. W „lustrze” człowieka szalonego świat przegląda się w swojej często tylko pozornej normalności. Bohater dotknięty takim czy innym szaleństwem znajduje miejsce w literaturze. Podobnie jak szalony pisarz. Markiz de Sade, Hölderlin, Nerval, w innym wymiarze Franz Kafka, Fernando Pessoa i Charles Bukowski powierzaja słowom własne szaleństwo lub fascynację szaleństwem, budując nierozdzielny krạg wyjątkowych opowieści. Są wiarygodni, albowiem ze swojego życia kreują świat przedstawiony, w którym normalność i zwykłość przestają być normalne i zwykłe. Nie dotykajmy tu jednak tajemnicy tworzenia na granicy obłędu - to zbyt skomplikowana materia. Zadaję sobie tylko naiwne pytanie: czy tym samym prawom „szalonej twórczości" mogą również podlegać komentatorzy literatury? Znam badaczy, z którymi kontakt na poziomie pracy wydawniczej jest niezmiernie utrudniony, tak bardzo sa przekonani o swojej nieomylności i wszechwiedzy. To przecież też rodzaj nieuświadamianego szaleństwa, przynajmniej w niektórych przypadkach.

Czy język metaliteracki podlega podobnym procesom co wypowiedź literacka i staje się świadectwem choroby własnej piszącego? Niekiedy można odnieść takie wrażenie w gmatwaninie specjalistycznych żargonów, skrywających za kotarą nadmiaru słów zwykłe nieporozumienia i pozorne odkrycia, byle komunikat sprawiał wrażenie „nowoczesnej oryginalności”. Filtr racjonalności staje tu na straży? Chyba nie. Zapytajmy tedy: czy edytorskie rzucanie sie „z motyką na słońce”, próby realizacji projektów niemożliwych do zrealizowania $\mathrm{z}$ powodów uchodzacych za obiektywne (biologia, ekonomia, utajone problemy ze zdrowiem) sa przykładem naukowego „bezrozumu” tudzież przejawem pychy „czystego” rozumu? A może szaleństwo w literaturze i literaturoznawstwie (także w edytorstwie) to warunek konieczny, by obie dziedziny w ogóle istniały? Wszak określając się wobec literackich „bohaterów szalonych" i równie niekiedy szalonych pisarzy, literaturoznawca może utwierdzić się w przekonaniu o swojej bezprzykładnej normalności, czyli racjonalnej postawie wobec piszących szaleńców bądź postaci ze świata przedstawionego, których zacho- 
waniom trudno nadać miano „normalnych” (vide: romantyzm) ${ }^{1}$. Tak czy owak, wydaje się, że między szaleństwem a "normą" w świecie literackim (i do pewnego stopnia literaturoznawczym) istnieje tylko subtelna granica, każdorazowo zależna od indywidualnych predylekcji piszacych, ich talentów oraz egocentrycznych w gruncie rzeczy zapatrywań co do skali własnych możliwości.

Nie sposób przy tym zastosować swobodnie definicji psychologicznych czy klinicznych terminu „szaleństwo” w odniesieniu do literatury (i literaturoznawstwa), gdyż w naszej dziedzinie, podobnie jak w każdej niemal dziedzinie sztuki, relacje między normą a „nie-normą” są bardzo płynne i zależne od poszczególnych wyjątkowych osobowości, które trudno sprowadzić do behawioralnych danych uogólnianych w ramach tzw. typów zachowań osobowych ${ }^{2}$. W „czarnej legendzie” Andrzeja Towiańskiego, znakomicie przedstawionej ongiś w doktoracie Leszka Skrzypka, motyw szalonej osobowości Mistrza ujawnia się wielokrotnie ${ }^{3}$. Ale cóż począć, gdy ów mistyczny szaleniec pociaga za sobą innych wyznawców? Czy stają się oni również szalonymi pomazańcami? Konrad Górski relacjonuje przygody Mickiewicza „w krainie czarów Mistrza”, wykazuje spustoszenia, jakie w umyśle poety spowodowało tzw. Koło Sprawy Bożej, tropi ślady „na szlakach błędu i obłędu” Mickiewicza, ale jednoznacznej odpowiedzi co do szaleństwa poety i jego kierownika duchowego nie udziela ${ }^{4}$. Komentatorzy literatury i sztuki często zadowalają się potocznym rozumieniem terminu „szaleństwo”, traktując je jako zespół zachowań odbiegających od racjonalnej normy ${ }^{5}$. To bezpieczniejsze, choć kapitulanckie podejście. Odważniejsi sa psychologowie i psychiatrzy, którzy omijają opisowe pojęcie szaleństwa i mówią wprost o paranoicznej osobowości, paranoidalnej strukturze psychiki, paranoidalnym pragnieniu wielkości i paranoicznej pysze choćby Mickiewicza ${ }^{6}$. Słusznie dostrzega Anita Całek, że nienormatywne czy też nieracjonalne zachowania poetów i artystów są dość powszechne, ale „terminy "obłęd" i "szaleństwo" to pojęcia zbyt wieloznaczne i szerokie, by ich używać współcześnie; są w dodatku kulturowo uwarunkowane, więc trudno doprecyzować treści, jakie się za nimi kryja" ${ }^{7}$. Tytułowe szaleństwo należy więc w przestrzeni tego tekstu rozumieć metaforycznie, nieco podobnie jak w diagnozie filozoficznej Henryka Elzenberga, który $\mathrm{w}$ Kłopocie $\mathrm{z}$ istnieniem rzecz ujął w następujący sposób:

1 Zob. m.in. A. Kow a l z zy k ow a: Romantyczni szaleńcy. Warszawa 1977; Ciemne drogi szaleństwa. Kraków 1978.

2 Z ogromnej literatury przedmiotu na ten temat warto zwrócić uwagę na pozycje klasyczne, które można wyzyskać do opisu literackiej i okołoliterackiej rzeczywistości - zob. m.in. K. Dą browski e go Trud istnienia (Warszawa 1986) i A. Kępińs ki e go Psychopatie (Kraków 1992).

3 L. Sk r zy p e k, Legenda Mistrza Andrzeja. Fenomen towianizmu $w$ latach 1841-1878. Rozprawa doktorska napisana pod kier. prof. Z. Przychodniaka. Poznań 2009 (w archiwum UAM).

4 Zob. K. Gó r s ki, Mickiewicz-Towiański. Warszawa 1986.

5 Stownik języka polskiego PWN (t. 3. Warszawa 1985, s. 391) jako najbardziej rozpowszechnione ujęcie tego terminu podaje następującą definicję szaleństwa: „postępowanie wykraczające poza przeciętne normy, zwyczaje; postępek nie liczący się z niebezpieczeństwem”.

6 Zob. J.-Ch. Gille-Ma is a ni, Adam Mickiewicz. Studium psychologiczne. Od dzieciństwa do „Dziadów części trzeciej”. Przekł. A. Ku ry ś, K. M a r c ze w s ka. Warszawa 1996, m.in. s. 199-201, 212, 217, 260, 265.

7 A. Całe k, Adam Mickiewicz - Juliusz Stowacki. Psychobiografia naukowa. Kraków 2012, s. 402. 
Twórczość to $z$ samej treści pojęcia zapuszczanie się w coś nieznanego. A są tylko dwa światy, które mogą zawierać coś nieznanego całkowicie i bez zastrzeżeń: świat śmierci i świat szaleństwa. Szaleństwo więc i śmierć to najlepsze, najostrzejsze symbole twórczości. Ale to nie znaczy, by miały stać się ulubioną treścią! ${ }^{8}$

Możemy stronić od szaleństwa w nauce o literaturze. Ale jeśli zgodzimy się, że interpretacje tekstów literackich oraz komentarze rozmaitej proweniencji przynależą do form twórczości okołoliterackiej, to musimy przyjąc, iż szaleństwo istnieje i pośród nas - literaturoznawców. Trafny wydaje się więc tytuł jednej z części książki zbiorowej młodych adeptów humanistyki poświęconej zjawisku szaleństwa: Patologia normalności i normalność szaleństwa w literaturze ${ }^{9}$, przy czym wystarczy zamienić wyrażenie „w literaturze” na określenie „w edytorstwie” i od razu stajemy in medias res w teatrze trudnych relacji na polu filologii.

Wskazaną w tytule tego eseju formułę szaleństwa - podkreślmy raz jeszcze należy traktować umownie, z możliwością waloryzacji negatywnej lub pozytywnej. Nie o chorobach psychicznych edytorów będzie mowa (choć i te się zdarzaja), ale o pewnym specyficznym nastawieniu do przedmiotu działań edytorskich, które pod pozorami postawy racjonalnej kryje w sobie jednakowoż zalążek szaleństwa tak co do pomysłów czy koncepcji, jak i sposobów realizacji. Akcentuję tu właśnie owo praktyczne nastawienie i racjonalność naukowa, albowiem edytorstwo to dziś nade wszystko domena konkretu, w której koncept, często w swojej istocie idealistyczny, zderza się $z$ rzeczywistością tekstu, $z$ jednej strony, oraz praw ekonomii wykonania $-z$ drugiej, a te nie zawsze dostatecznie brane sa pod rozwagę i namysł.

Czytając artykuł Edytorstwo w nowym wydaniu Encyklopedii ksiażki, trudno zgodzić się z anachronicznym modelem przypisywania edytorstwa do dziedziny „bibliologii”, przeciwstawianej „edytorstwu praktycznemu”, ale w haśle następnym, Edytorstwo. Praktyka, przytomnie zwraca się uwagę na szczegółowe zagadnienia, m.in. aspekty wydawnicze, prawne, graficzne, opracowanie redakcyjne, przygotowanie plików do edycji czy realia ekonomiczne, a więc na te elementy współczesnej „sztuki edycji”, które często są pomijane lub spychane na plan dalszy w myśleniu o wydaniu dzieła ${ }^{10}$, gdyż edytor-filolog lub edytor-historyk sprowadzają swoją rolę zazwyczaj do jednego wymiaru: tekstologa czy też - jak kto woli - krytyka tekstu albo wydawcy źródeł. Jest to oczywiste nieporozumienie. W rezultacie powstaja, a raczej ostatecznie nie powstają, edycje „wyśnione”, realne tylko w teoretycznym zamierzeniu, edytorskie projekty źle przygotowane od początku, trudne do realizacji z różnych powodów. Przyczyny niepowodzeń szalonych pomysłów są dla mnie ciekawsze od samych założeń wstępnych „idealistycznych” projektów - mrzonek.

Nie mam zamiaru przypisywać tych przypadłości niektórym współczesnym i dawnym edytorom; moim zadaniem jest tylko wskazanie błędnych założeń oraz postaw, które uniemożliwiają w dużym stopniu realizację takiego czy innego sza-

H. E 1 z e n b erg, Kłopot z istnieniem. Aforyzmy $w$ porzadku czasu. Wyd. 2, zmien. i uzup. Kraków 1994, s. 83 (zapis z września 1913).

9 Zjawisko szaleństwa w kulturze. Red. M. Kas prowicz, S. Drelich, M. Kopy ciński. Toruń 2010, s. 135.

10 Zob. hasła: B. H., Edytorstwo; E. J.-S., A. W., Edytorstwo. Praktyka. W: Encyklopedia ksiażki. T. 1: Eseje A-J. Red. A. Żbikow ska-Migoń, M. Skalska-Zlat. Wrocław 2017, s. 600-608. 
leńczego projektu w dzisiejszych uwarunkowaniach, interesuje mnie też zaakcentowanie pozytywnych realizacji szaleństw edytorskich, które zakończyły się sukcesem lub mają na to szansę. Raczej nie wspominam (z małymi wyjątkami) o pomysłach racjonalnie uzasadnionych, bo te kończą się zazwyczaj powodzeniem. I jest ich coraz więcej. Stopień ogólności w mojej wypowiedzi będzie przeważał nad szczegółowym roztrząsaniem konkretnych przykładów. Można przecież już we własnym zakresie zatoczyć szeroki krąg egzemplifikacji i wypełnić pola zasugerowane przez autora tych luźnych rozważań. I jeszcze jedno zastrzeżenie: są to subiektywne przemyślenia, nie pretendujące w żadnym wypadku do miana uwag nieomylnych, nadto stosuję nieraz przejaskrawienia - z nadzieją, że dadzą asumpt do ewentualnej dyskusji, która dziś w edytorstwie niemal zamarła. Nie poczuwam się przy tym do malkontenctwa, sukcesywnie wyrażanego swego czasu na Zjazdach Polonistów, i zdecydowanie bliższa jest mi diagnoza Adama Karpińskiego, obserwującego od początków XXI wieku stały rozwój edytorstwa, czemu sprzyjają także nowe zdobycze technologiczne. Współczesny edytor „zyskał narzędzia wspomagające w sposób istotny tę część warsztatu, którą określić można jako erudycję filologiczną, pozwalająca na prawidłowe ustalenie tekstu, jego rozumienie i komentowanie" ${ }^{11}$.

Już samo założenie wyjściowe dla większości filologów (zwłaszcza krytyków tekstu) jest na pewno kontrowersyjne, by nie powiedzieć - obrazoburcze. Zakładam bowiem, że w sytuacji, w jakiej znalazło się dziś edytorstwo naukowe, należy orientować się w wielu szczegółowych dziedzinach wiedzy i w zmieniających się okolicznościach zewnętrznych (pozatekstowych), co przekracza pojmowany zwyczajowo zakres obowiązków filologa. Nie tylko gromadzenie i badanie źródeł, przygotowanie podstawy tekstowej, umiejętność sporządzenia komentarza filologicznego sa warunkami powodzenia przedsięwzięcia edytorskiego, ale i sposób opracowania redakcyjnego tekstu, aspekt graficzny (w tym typografia), wycena ekonomiczna, podstawowa znajomość środowiska technologicznego oraz zaplecza informatycznego, a także troska o dalsze losy dzieła (rynek wydawniczy, promocja). Wszystkie te elementy muszą być brane pod uwagę przy projektowaniu wydania. Właśnie... przy projektowaniu! Czy to oznacza, że filolog musi znać się na wszystkim, co związane jest $z$ działaniami przygotowawczymi (technicznymi) i wydawniczymi? Oczywiście, że nie. Jednak znajomość choćby podstawowych reguł praktycznych skomplikowanego procesu edytorskiego, także zmieniającej się dynamiki rynkowej, oraz wiedza $z$ zakresu informatyki czy technologii druku, by nie wspominać już o podstawowym wymiarze ekonomicznym, umożliwią właściwy dobór współpracowników, którzy na następnych etapach przygotowywania edycji będą profesjonalnie zajmować się konkretnymi zadaniami. Tylko zespołowa praca w gronie zaufanych i znających się na rzeczy osób odpowiedzialnych za konkretne działania pozwala dziś przygotować do druku edycję naukową i zamiar skutecznie zrealizować do końca, bez względu na to, czy projekt dotyczy wybranej pozycji z dorobku pisarza czy też obszernego zbioru jego dzieł. Na pewno nie uda nam się już powrócić do niedawnych jeszcze czasów biurkowej filologii bez konieczności wychodzenia $z$ gabinetu do składu komputerowego czy drukarni, a co gorsza - bez pukania do drzwi instytu-

11 A. Ka r pińs ki, Edytorstwo i krytyka tekstu w Polsce u progu XXI wieku. W zb.: Humanizm i filologia. Red. ... Warszawa 2011, s. 507. 
cji pomagającej udźwignąc finansowo przedsięwzięcie. Nie wystarcza zebrania naukowe $\mathrm{w}$ gronie podobnych sobie znawców. Realia technologiczne tak szybko tworzą nowa jakość, że albo filologia dostosuje się do tych przemian, albo zaniknie. To moja kontrowersyjna teza wyjściowa, którą wielokrotnie już wypowiadałem na sympozjach i spotkaniach poświęconych edytorstwu.

Filolog współczesny, czy mu się to podoba, czy też nie, musi wziąć pod uwagę zmieniające się uwarunkowania technologiczne i ekonomiczne, co nie znaczy - podkreślam raz jeszcze - że powinien je wszystkie opanować w szczegółach. Ale na pewno nie można już beztrosko formułować przekonań wyjętych wprost $z$ mało aktualnego (przynajmniej w aspekcie edytorstwa praktycznego) podręcznika Konrada Górskiego, który zwykł był bardzo ostro rozdzielać pracę uczonego filologa, wydawcy oraz zatrudnionego przezeń redaktora technicznego i korektora. Górski twierdził, że wydawca, „otrzymawszy do ręki jakiś gotowy tekst, przygotowuje go do druku, organizuje techniczną stronę jego powielenia i puszcza w obieg handlowy"12. Owszem, i dziś wydawca organizuje cały proces druku, jednak bez dostarczenia odpowiednio sformatowanego tekstu na nośniku elektronicznym, bez wskazówek graficznych, bez wstępnego projektu typograficznego i planowanej struktury edycji nic nie wykona właściwie. I nie dlatego, że jest marnym fachowcem, ale z powodów technicznych. Zmiany technologiczne zdominowane przez komputerowy proces obróbki tekstu bez wątpienia ułatwiaja jego przygotowanie i szybkie opublikowanie, pod jednym wszak warunkiem: ścisłej współpracy z edytorem nie tylko na poziomie korekty tekstowej. Jednak i dziś pokutujące jeszcze dawne przyzwyczajenia edytorów często odbiegają od współczesnych standardów pracy wydawniczej, o czym mogłem się niejednokrotnie przekonać jako nomen omen wydawca akademicki.

$Z$ tej też perspektywy - ratio i praxis - przyglądam się zmaganiom współczesnych edytorów i stwierdzam, że nie wystarczy znakomicie pod względem naukowym przygotować tekst, należy jeszcze w dzisiejszych realiach dopilnować jego właściwej prezentacji. Wbrew pozorom to zadanie okazuje się najtrudniejsze. Wszystkie sprawy techniczne załatwiało niegdyś wyspecjalizowane wydawnictwo i można się było skupić tylko na pracy naukowej z tekstem, o czym przekonują Stanisław Pigoń, Konrad Górski, Zbigniew Goliński, Zbigniew Jerzy Nowak, Czesław Zgorzelski, Zofia Stefanowska oraz inni znakomici edytorzy czasów minionych. Ale realia zmieniły się radykalnie. Wydawca wprawdzie chętnie (bądź mniej chętnie) spełni wszystkie (lub niemal wszystkie) sugestie edytorów, szkopuł w tym, że muszą być one wyrażone w języku dobrze zrozumiałym dla obu stron, z czym jest niekiedy poważny kłopot. Współczesny wydawca nie będzie wiedział, czego oczekuje od niego uczony, jeśli ten jasno i precyzyjnie nie określi horyzontu własnych wyobrażeń co do kształtu edycji. Nie ma już dawnych instytucji, rzesz znakomitych redaktorów, wydawnictwa nie zatrudniają tłumu pracowników, którzy swoje życie podporządkowaliby w całości pracy, jak to drzewiej bywało, choćby i na rzecz najbardziej zasłużonego profesora, bo zwyczajnie muszą zadbać o swoje utrzymanie; tym samym aspekty ekonomiczne wymuszaja takie, a nie inne cele, działania i priorytety. Tytułowe szaleństwo edytorów znakomicie ujawnia się właśnie we wskazanej optyce.

12 K. Górski, Tekstologia i edytorstwo dzieł literackich. Wstęp M. Strzyżewski. Wyd. 3, popr. i uzup. Torun 2011, s. 209. 


\section{Szaleństwo edycji nieustającej dzieł wszystkich}

Cechą charakterystyczna takiej edycji jest to, że nigdy się ona nie kończy. Trwa ciągle, by nie powiedzieć: wiecznie, i toczy się własnym życiem przez pokolenia. Zazwyczaj późny wnuk doczeka się ostatniego tomu, choć nie zawsze. Któż to raczy wiedzieć. To ewidentne przedsięwzięcia $\mathrm{z}$ kręgu horror curiosum. Tak zresztą często bywało $\mathrm{u}$ nas i w przeszłości. Uczeni zawsze tłumaczyli się $\mathrm{z}$ tego rozciagniętego w czasie wielotomowego potwora a to brakiem środków, a to nadmiarem pracy lub okolicznościami szczególnymi, które uniemożliwiają dokończenie przedsięwzięcia. Znamienne, że to zawsze czynniki zewnętrzne determinują, ich zdaniem, w tak wielkim stopniu wydłużenie się pracy nad daną edycją, nigdy własna nieudałość organizacyjna czy zwykły brak kompetencji. W czasach tzw. gospodarki państwowej profesor kierujący zespołem edytorów zazwyczaj nie przejmował się brakiem środków finansowych, ale wyjaśniał niepowodzenie niedostatecznym przydziałem papieru, obstrukcją polityczną, wykruszaniem się zespołu, etc. Tylko niekiedy były to tłumaczenia prawdziwe, częściej przy dużych projektach ujawniała się nieumiejętność opanowania sporego warsztatu naukowego, nadto z wieloma współpracownikami. Zmieniały się koncepcje, co zrozumiałe, umierali wykonawcy, co też zrozumiałe, zważywszy na trwanie prac przez 30 czy 40 lat, a nawet pół wieku. Ten, kto rozpoczynał edycję, zazwyczaj nie doczekiwał jej końca, po drodze także współpracownicy pierwszego redaktora naukowego odchodzili z zespołu $z$ różnych powodów. I ten stan rzeczy wpłynął, jak sądzę, destrukcyjnie na dziedzinę edytorstwa w ogóle. Otóż przyjęło się uważać, że praca nad wielkimi wydaniami krytycznymi musi być długotrwała i kosztochłonna, z tym że kosztów nie można zliczyć wiarygodnie wskutek upływu dziesiątków lat, a więc i zaplanować ciągu dalszego danego przedsięwzięcia. Do tego stopnia utrwalił się mit o konieczności długiego celebrowania edycji zbiorowej, że w opracowaniach podkreśla się nieraz nawet niezbędność długiego trwania prac ${ }^{13}$. Oczywiście, wiele skomplikowanych przedsięwzięć wydawniczych wymaga odpowiedniego czasu realizacji, powinny jednak mieć one swój początek i swój koniec. Tymczasem istnieją nigdy nie zakończone projekty, które rozpoczęły się głęboko w czasach komunizmu i nie mogą nadal ziścić się w okresie gospodarki rynkowej (m.in. wydania krytyczne pism Jana Kochanowskiego, a do tej grupy można już policzyć i „młodszego”, lubelskiego Norwida). To doprawdy swoisty polski fenomen.

Warto się zastanowić głębiej nad prawdziwymi przyczynami istnienia takich rozciągniętych w czasie ponad miarę dziwów edytorskich. Nie potrafię, rzecz jasna, wszystkich powodów zwerbalizować, ale uważam, że najczęstszym źródłem klęski jest rozpad nieumiejętnie dobranego zespołu, brak zdolności organizacyjnych kierowników przedsięwzięć, zachwianie priorytetów i zmiana koncepcji naukowych, ignorowanie zasad logistyki, nienadążanie za rozwojem technologicznym, brak

13 W przywołanej tu już Encyklopedii ksią̇ki, w haśle Krytyczne edycje literackie (t. 2, s. 101), czytamy: „Przygotowanie K.e.l. trwa nierzadko kilkanaście-kilkadziesiąt lat, gdyż opracowanie krytyczne samych tekstów musi być poprzedzone badaniami bibliograficznymi, które mają na celu dotarcie do wszystkich wariantów tekstu (rękopiśmiennych i drukowanych) oraz ustalenie właściwej podstawy wyd.". 
dbałości o zaplecze redakcji technicznej, wreszcie i trudności w gospodarowaniu środkami finansowymi, jak zwykle, w każdym czasie, zbyt małymi. Utarło się również, że po zmarłym redaktorze naukowym rzecz swoiście dziedziczy jego bliski współpracownik. Ale czy zawsze ma on odpowiednie predyspozycje do dalszego prowadzenia prac? Można też dodać niewłaściwe rozpoznanie dokumentacji tekstowej oraz sztywne trzymanie się raz przyjętych założen, co skutkuje często dylematami nie do rozwiązania, gdy nadmiar skomplikowanych, trudnych do odczytania rękopisów niełatwo należycie uporządkować i ocenić zgodnie $\mathrm{z}$ zasadami krytyki tekstu. Wszak przyjęło się u nas także sądzić, że wydanie krytyczne zbiera całą dokumentację i wszystkie źródła, istotne i mniej ważne, a nawet bzdurne z punktu widzenia ich wpływu na powstanie ostatecznej wersji utworu, rozsadzając tym samym projekt edytorski od wewnątrz. Edytorstwo jako „sztuka dla sztuki” to wypaczenie naukowej filologii! Kurczowe trzymanie się tradycji i pokutujace mity edytorskie to dziś kierunek donikąd. Dodajmy i ten logiczny warunek: $z$ racji dużych kompetencji naukowych pomysłodawcy wydania w żaden sposób nie wynika jeszcze powodzenie realizacyjne. Napotykamy tu następny mit redaktora - uczonego o znakomitym dorobku naukowym, któremu nie sposób się sprzeciwić, gdyż cieszy się on wielkim uznaniem i autorytetem w swoim środowisku. Ów uczony nie przystaje jednak do rzeczywistości współczesnej, która zyskała nowe oblicze z powodów choćby zmian technologicznych, obowiązującej formuły cyfrowej oraz realiów ekonomicznych. Tak więc, by uniknąc pętli szaleństwa nieustajacych „edycji w toku”, trzeba zmodyfikować sposób myślenia o współczesnym edytorstwie naukowym i zdać się przede wszystkim na młodych współpracowników, podążających za nowymi tendencjami w standardach wydawniczych. Inaczej proces stagnacji będzie się tylko pogłębiał.

\section{Szaleństwo koncepcyjne}

To wariant swoistego szaleństwa edytorskiego blisko spokrewniony z „szaleństwem nieustającej edycji” tudzież bezpośrednio z niego wyrastający. Owe typy szaleństwa na pewno wzajem się warunkują. Mam tu na myśli szaleństwo koncepcji zbierania wszystkich przekazów i wersji tekstowych, by wepchnąć je następnie do książki w zazwyczaj nieczytelnym komentarzu filologicznym. Dziś może do tego celu służyć dobrze zaprojektowane wydanie elektroniczne $z$ przejrzystym i bogatym hipertekstem. Jeśli edytor uważa za słuszne przedstawić proces powstawania dzieła, wskazać relacje między zmieniającym się rękopisem (wielość skreśleń i dopisków) a ostatecznym kształtem tekstu, to może w przestrzeni internetowej zaprojektować i zrealizować modelową edycję dokumentacyjną czy genetyczną bez szkody dla literackiego przekazu; przecież odbiorcę (także profesjonalnego) interesuje nade wszystko poprawność przekazu, a niekoniecznie już warsztat, edytorskie śledztwa, wariantywność czy sposoby pracy danego autora nad własnym utworem w rękopisie. Tradycyjny wolumin książkowy może więc bez naukowej szkody funkcjonować jako rzeczywisty artefakt literacki, a nie popis edytorski. Odpowiada mi w tym zakresie praktyka francuskich wydawnictw, m.in. Gallimarda i Classiques Garnier, które potrafiły wypracować model edycji naukowej bez konieczności straszenia potencjalnych czytelników jej nienaturalną objętością i hermetycznością. Mocno zachęcam więc Marka Troszyńskiego, by zrealizował swoją szaloną ( $\mathrm{z}$ racji ogromu 
przedsięwzięcia), choć w założeniach na pewno zdroworozsądkową, wizję wydania internetowego Dzieł wszystkich Juliusza Słowackiego ${ }^{14}$, wszak z edycji dawnej, powstającej zresztą niemal pół wieku (wliczając $w$ to pierwsze tomy przedwojenne), nie sposób dziś korzystać ${ }^{15}$. Dominujący tam układ z podziałem na dzieła wydane za życia poety i dzieła pośmiertne spowodował, jak wiadomo, rozbicie wielu utworów Słowackiego, nie mówiąc już o dodatkowym gatunkowym ich poćwiartowaniu. Kleiner nie okazał się tu szalonym wizjonerem na miarę Słowackiego, ale szalonym edytorem, który wypracował wątpliwą koncepcję wyjściową Dzieł wszystkich, i mimo wielu cennych odkryć, koniektur i emendacji tam zawartych ${ }^{16}$ wskazane jest dziś korzystanie $z$ częściowych tylko, acz starannych i przejrzystych edycji krytycznych Zbigniewa Przychodniaka i Jacka Brzozowskiego (Wiersze, Poematy, Beniowski) ${ }^{17}$ oraz z dokumentacyjnych i genetycznych wydań Marka Troszyńskiego (Raptularz 1843-1849, Samuel Zborowski) ${ }^{18}$, przywracających pierwotna, a utraconą w edycji Kleinera całość tekstów Słowackiego.

\section{Szaleństwo egotycznej próżności}

To bardzo niebezpieczny i spektakularny nieraz wyraz fiaska zamierzenia edytorskiego, którego przyczyna tkwi zazwyczaj w specyficznej osobowości redaktora naukowego. Zbiera się oto grono znakomitych uczonych oraz edytorów z dużym doświadczeniem, celem jest wydanie krytyczne dzieł wszystkich narodowego poety i mimo ogromnego potencjału intelektualnego nie sposób owego celu osiagnać. Istnieja jakie takie warunki organizacyjne, finansowe, istnieje ogólny projekt edycji, ale do głosu dochodza indywidualne ambicje, kłopoty z przyjęciem określonego stanowiska w sprawach szczegółowych, forsowanie nieakceptowalnych koncepcji modernizacyjnych i w rezultacie wieszcz narodowy Adam Mickiewicz nie doczeka się w pełni krytycznego wydania, gdyż edytorzy ostatecznie nie doszli do porozumienia m.in. w kwestii przyjęcia wybranego modelu przestankowania ${ }^{19}$. To grote-

Zob. interesujacy wywiad A. G r a b o w s k i e g o z M. Troszyńskim: Ten bezczelny Stowacki! „Nowe Książki" 2020, nr 7/8, s. 4-9.

15 Pełne wydanie powojenne pod redakcja J. Kleinera i W. Floryana wyszło w 17 tomach w latach 1952-1975 we wrocławskim wydawnictwie Ossolineum; tom 1: Wiersze, pierwotnie w ramach Dzieł wszystkich J. Słow a cki e g o, ukazał się w 1924 roku.

16 Gruntowną recenzję całości edycji opublikował K. G ó rs k i (O krytycznym wydaniu „Dzieł wszystkich” Juliusza Stowackiego. „Pamiętnik Literacki” 1976, z. 1). Wynika z niej, że już w czasie ukazywania się poszczególnych tomów zdawano sobie sprawę z poważnych mankamentów przyjętych wstępnie założeń edytorskich oraz z niekonsekwencji realizacyjnych.

Zob. J. Sło w a c ki: Wiersze. Nowe wydanie krytyczne. Oprac. J. Brzozow s ki, Z. Przy ch odniak. Poznań 2005; Poematy. Nowe wydanie krytyczne. Oprac. J. Brzozowski, Z. Przychodniak. T. 1: Poematy z lat 1828-1839; t. 2: Poematy i fragmenty z lat 1842-1849. Poznań 2009; Beniowski. Poemat z roku 1841 i dalsze pieśni. Nowe wydanie krytyczne. Oprac. J. B r z ozowski, Z. Przychodniak. Poznań 2014.

18 Zob. J. Sło w a k ki, Raptularz 1843-1849. Pierwsze całkowite wydanie wraz z podobizna rękopisu. Oprac. edytorskie, wstęp, indeksy M. Troszyński. Warszawa 1996. - M. Troszyński, Alchemia rękopisu. „Samuel Zborowski” Juliusza Słowackiego. Warszawa 2017.

19 Pisze o tym zresztą sam K. Gó r s ki w Autobiografii naukowej („Kwartalnik Historii Nauki i Techniki” 1982, nr 3/4), przypominając o konieczności przywrócenia właściwych poecie form języka staropolskiego oraz interpunkcji intonacyjno-retorycznej, zgodnie $z$ wypracowanym przez siebie 
skowy wymiar edytorstwa. Niestety, zdarza się u nas. Problemy z wypracowaniem wspólnego założenia i uparte trwanie przy własnych mniemaniach nie prowadzą zazwyczaj do pozytywnego zwieńczenia zaplanowanego na wiele lat przedsięwzię$\mathrm{cia}^{20}$. Abstrahując już od tego wstydliwego przykładu, należy raz jeszcze podkreślić, że trudności ze stworzeniem przez kierownika grantu odpowiedniego zaplecza organizacyjnego i logistycznego (finanse, redakcja, zespół korektorów, współpraca ze składem komputerowym), brak zaufania do współpracowników, skutkujący sprawdzaniem wszystkich i wszystkiego, współtworzą także i dziś przeszkody, których ostatecznie nie daje się pokonać, i przedsięwzięcie musi zostać przerwane. Egotyzm i próżność części edytorów to ich szaleństwo osobiste, uniemożliwiające racjonalne działanie. Na szczęście nie są to przypadki częste, ale mimo wszystko bolesne. Przykłady można by mnożyć, jednak wolę zamilczeć.

\section{Szaleństwo udaremnione „próbą zdrowego rozumu”}

To z kolei pozytywna przeciwwaga dla szalonych pomysłów „wyśnionych”, nie mających szans powodzenia $z$ racji uwarunkowań koncepcyjnych tudzież ograniczeń osobowych. Zofia Stefanowska jako redaktor naukowy Pism Mickiewicza w porę wycofała się z pierwotnej koncepcji, by wykłady paryskie poety z lat 1840-1844 opublikować w nowej wersji, popartej rzetelną krytyką tekstu. Trudności merytoryczne, jakie spiętrzyły się przed zespołem badaczy, uniemożliwiły ostatecznie dokonanie edytorskiej „rewolucji” i wydanie krytycznie opracowanego przekładu filologicznego. Zamiast tego zdecydowano się zamieścić w edycji pierwotne tłumaczenie Feliksa Wrotnowskiego, znane romantykom ${ }^{21}$. Ale i do tego nie doszło. Następne problemy, jakie ujawniły się przy analizie zakładanej podstawy tekstowej (a raczej wielu podstaw), niejako zmusiły redaktorkę do poprzestania tylko na odświeżeniu dobrze już zadomowionego w kulturze przekładu Leona Płoszewskiego, ze świadomością niedoskonałości, a nawet w wielu miejscach dowolności tej translacji. Dla Stefanowskiej była to decyzja bardzo trudna, acz nieodzowna, uwarunkowana przede wszystkim problemami merytorycznymi oraz koniecznością wykonania niełatwego przedsięwzięcia w określonym czasie ${ }^{22}$. Mimo świetnego zespołu edytorskiego nie udało się zrealizować ambitnego zamiaru. Zniszczenie części stenogramów, trudności w dotarciu do wiarygodnych źródeł, wymóg precyzyjnego porównania wszystkich istniejących przekładów francuskich, niemieckich

pojęciem woli autorskiej. Nie podaje jednak przyczyn niepowodzenia realizacji edycji krytycznej Dziet wszystkich Mickiewicza.

Ostatecznie w ramach wydania krytycznego Dziet wszystkich A. Mickiewicza pod redakcją K. Górs ki e go opublikowano tylko Pana Tadeusza (Oprac. K. Górski. Wrocław 1969), jako tom 4, oraz Wiersze (Oprac. Cz. Zg or zels ki), jako tom 1 - cz. 1: 1817-1824 (Wrocław 1971); cz. 2: 1825-1829 (1972); cz. 3: 1829-1855 (1981); cz. 4: Uzupetnienia i materiaty (1986).

21 Sprawozdania $z$ badań filologicznych dotyczących możliwości powstania edycji krytycznej zbiera zeszyt Wydanie krytyczne prelekcji paryskich Adama Mickiewicza. Materiały do dyskusji (Oprac. M. Prussak, Z. Stefanowska, M. Troszyński. Warszawa 1994), przygotowany przez Komitet Redakcyjny Pism Mickiewicza.

22 Ostatecznie cztery kursy wykładów Mickiewicza ukazały się w Wydaniu Rocznicowym jako tomy 8-11 (Warszawa 1997-1998) w opracowaniu J. Maślanki i w przekładzie L. Płoszewskiego. 
i polskich przekraczały możliwości zespołu. Szalony pomysł, by udostępnić czytelnikom rzetelny przekład filologiczny, musiał więc zostać odłożony.

Także i wariant drugi nie doszedł do skutku. Do dziś nie wiemy, jakie fragmenty były konsultowane $z$ Mickiewiczem, gdy Wrotnowski przygotowywał swoje tłumaczenie. I w tym przypadku nie udało się określić wiarygodnie podstawy tekstowej. Prelekcje paryskie stanowią tedy ciagle prawdziwe wyzwanie dla filologii polskiej ${ }^{23}$. Nadal skazani jesteśmy na korzystanie $z$ kompilacyjnej translacji Płoszewskiego, nie spełniającej warunków współczesnej filologii. Jeden z najważniejszych przekazów naszej kultury romantycznej interpretatorzy odczytują w bardzo niedoskonałej wersji, której Mickiewicz na pewno nie stworzył ${ }^{24}$.

Przykład postawy Stefanowskiej był inspirujący także dla mnie - w pewnym momencie pracy nad wydaniem krytycznym spuścizny literackiej Zygmunta Krasińskiego wycofałem się $\mathrm{z}$ zamiaru ogłoszenia edycji w pełni krytycznej. $\mathrm{W}$ tym przypadku dojmujący brak źródeł rękopiśmiennych ostatecznie przekreślił pierwotny plan. Konieczne jest dziś postulowane coraz częściej w środowisku edytorskim przemyślenie na nowo terminu „edycja krytyczna” i odejście od tradycyjnych reguł rządzących komentarzem filologicznym. Warto niekiedy wycofać się $z$ ambitnego przedsięwzięcia, by w innym czasie, $z$ innymi możliwościami technicznymi i innym zapleczem organizacyjnym jeszcze do niego powrócić. Bez wątpienia istnieje sporo takich zarzuconych projektów wpisujących się w domenę szaleństwa edytorskiego $z$ racji ich stopnia trudności. Stefanowska pokazała, że dobrze jest stać na straży „Zdrowego rozumu” w marzeniach edytorskich. Mierz zamiary podług sił, możliwości i środków, choć próbować zawsze trzeba.

\section{Szaleństwo spełnione}

W historii edytorstwa jest wiele przykładów szaleństwa spełnionego. Można by temu zagadnieniu poświęcić długą rozprawę. Gdy mimo przeciwności losu i określonych problemów naukowych, coraz to nowych, pojawiających się wraz z kolejnymi zadaniami, udaje się ambitne zamierzenie doprowadzić szczęśliwie do końca, bez wątpienia mamy do czynienia $z$ szaleństwem spełnionym. Takim spełnionym edytorem na pewno jest dziś Janusz Degler, który doprowadził do finału ogromne przedsięwzięcie wydania Dzieł zebranych Stanisława Ignacego Witkiewicza. Tom pierwszy ukazał się w Państwowym Instytucie Wydawniczym w 1992 roku (622 upadki Bunga, czyli Demoniczna kobieta), ostatni zaś, 24 (Varia), w 2019 roku; na druk czeka jeszcze dwutomowa Bibliografia, już ukończona, która dopełni to szalone dzieło, choć Witkacy ponoć ciagle pisze, jako że nadal odnajdują się nie znane wcześniej listy czy notatki. Nad spuścizna Witkacego pracowały niemal trzy pokolenia badaczy z różnych ośrodków w kraju i za granica pod czujnym okiem i sub-

23 M. Prus s a k przedstawiła zagadnienie w syntetycznym artykule Problemy edytorskie wykładów Adama Mickiewicza $w$ Collège de France (w zb.: Prelekcje paryskie Adama Mickiewicza wobec tradycji kultury polskiej i europejskiej. Próba nowego spojrzenia. Red. M. Kali n ow s ka, J. Ła ws ki, M. Bizi or - D o m b r ow s ka. Warszawa 2011).

24 Pisałem o tym szerzej w artykule Znaczenie wykładów paryskich Mickiewicza w kulturze polskiej (w zb.: W cieniu Mickiewicza. Red. J. Ly s z c zyna, M. Bą k. Katowice 2006). 
telnym nadzorem Deglera, który niezależnie od własnej pasji badawczej potrafił w okresie bez mała 30 lat zjednać sobie szerokie grono uczniów i przyjaciół, a przy tym wykazać się konsekwencja, uporem i organizacyjnymi umiejętnościami w dążeniu do jasno wytyczonego celu.

Chciałbym tu zwrócić jeszcze uwagę na inny szalony zamysł, który znajduje się w fazie realizacji, ale zapewne już można mu przypisać miano spełnionego do pewnego stopnia szaleństwa edytorskiego. To wydanie krytyczne Pism wszystkich Bolesława Prusa pod redakcją naukową Beaty Obsulewicz. Instytucjonalnym patronem projektu jest Towarzystwo Literackie im. Adama Mickiewicza, środki zaś pozyskano z Narodowego Programu Rozwoju Humanistyki. Dotąd opublikowano 24 woluminy Pism (obejmujące 35 tomów) w przeciagu niespełna 6 lat (2014-2019). Tempo prac nad tą edycja jest doprawdy szalone. Nie będę tu omawiał jej założeń naukowych ani problemów, $\mathrm{z}$ jakimi codziennie stykają się edytorzy ${ }^{25}$. Chcę tylko zwrócić uwagę, że Beata Obsulewicz i grono jej współpracowników demaskują i unieważniają polski mit edytorski, jakoby rzecz tak obszerna i ambitna, zakrojona na wielką skalę, musiała być publikowana w ciagu kilkudziesięciu lat. Tytaniczny wysiłek badawczy i wydawniczy możliwy jest tylko przy sprawnej organizacji pracy oraz pozyskaniu profesjonalnych i oddanych sprawie współwykonawców. Do dużego zespołu lubelskiego należą uznani już badacze twórczości Prusa oraz grono młodych edytorów i adeptów literaturoznawstwa, dopiero zbierających doświadczenia. W sumie około 25 osób tworzy zespół edytorów i jednocześnie redaktorów poszczególnych tomów, do tego dochodzi 10-osobowa grupa korektorów. Ważny tu jest precyzyjny podział obowiązków i konsekwentne trzymanie się ustalonego harmonogramu działania, nad czym czuwa obok głównego redaktora naukowego także sekretarz przedsięwzięcia (Teresa Naumiuk). Istotny element edytorskiego procesu stanowi również sprawna współpraca ze składem komputerowym i jednocześnie wydawca (firma Episteme z Lublina). Należy życzyć Beacie Obsulewicz i wszystkim zainteresowanym całkowitego spełnienia owego bez watpienia szalonego zamierzenia: wydania pozostałej części spuścizny Bolesława Prusa.

Ten skromny objętościowo esej nie wyczerpuje złożoności zagadnienia, wylicza w metaforycznej formule „szaleństwa” tylko część przyczyn, dla których wiele projektów edytorskich nie zaistniało w przeszłości i nie może zaistnieć także dziś. Zdaję sobie sprawę $z$ subiektywności i dyskusyjności przedstawionych tez, mam jednak nadzieję, że wyostrzona forma tej wypowiedzi zwróci uwagę na pewne problemy „wewnętrzne” naszej dziedziny, która nie jest wszak tylko akademickim obszarem teoretyzowania, ale działalnościa praktyczną. Edytorstwo spełnia się w praktyce wydawniczej, nie zaś w konceptualizacjach. Czy szaleństwo w edytorstwie jest potrzebne? Śmiem watpić. Ale zawsze warto wypatrywać szalonych pomysłów i im towarzyszyć z życzliwością, by ujrzeć ostatecznie świetną realizację

Zob. na ten temat: B. K. O b sule wi c z, O edycji krytycznej „Pism wszystkich” Bolesława Prusa słów kilka. „Wiek XIX” 2015. - M. Kr eft, „Ćwiczenia na zastanawianie się”. O pracy edytora rękopiśmiennych notatek Bolesława Prusa. Jw. - E. Sk o r u pa, Nowa edycja „Kronik tygodniowych” Bolesława Prusa. Przykłady śledztw edytorskich. „Sztuka Edycji” 2017, nr 2: Filozofia przypisów. Red. M. Bizior-Dombrowska, B. Kuczkowski.-A. Bąbel, A. Grabowska-Kuniczuk, Bolesław Prus w przypisach i przypiskach. Studium przypadku. Jw. 
przedsięwzięcia, jak w przypadku wydań Witkacego czy Prusa. Jednak wówczas pierwotny zamysł staje się rzeczywistością i nikt już nie będzie pamiętał, że u jego podstaw tkwiła określona doza szaleństwa.

\author{
Abstract \\ MIROSŁAW STRZYŻEWSKI Nicolaus Copernicus University, Toruń \\ ORCID: 0000-0003-2020-656X \\ ON EDITORS' MADNESS IN THE PERSPECTIVE OF RATIO AND PRAXIS
}

The essay is devoted to considerations about irrational behaviour of some editors of Polish literature, which lead to academic and publishing failures. The reason of the failures are often insufficient compliance in editorial activities to the changing technological conditions, and problems with proper teamwork organisation. The situation in which the humanities, and editing as its basic domain, extorts from the philologists to constantly master academic workshop, adjust the workshop to new software and technological potential; it also induces the necessity to quit the old forms of work organisation. The essay also highlights the practical attitude and academic rationality as condition for success of the endavours, since editing is presently the domain of the concrete in which the idea, often idealistic (mad) in its nature, crashes with the text's reality on the one hand, and on the other hand with the laws of economy which are not always considered and reflected in research. 